\title{
URGENSI UPAYA MENJAGA MUTU PEMBELAJARAN DI TENGAH PANDEMI COVID 19
}

\begin{tabular}{|c|c|}
\hline \multicolumn{2}{|c|}{$\begin{array}{c}\text { Imam Subhi } \\
\text { STIT Kota Pagar Alam } \\
\text { elhafdatbi12@gmail.com }\end{array}$} \\
\hline Abstrak & \\
\hline $\begin{array}{l}\text { Article History } \\
\text { Received : } 31 \text { Juli } 2020 \\
\text { Revised : O1 Juli } 2020 \\
\text { Accepted : } 11 \text { Juli } 2020\end{array}$ & $\begin{array}{l}\text { This study aims to get a description } \\
\text { of efforts to maintain the quality of } \\
\text { learning in the midst of the covid } \\
\text { pandemic 19. The research method }\end{array}$ \\
\hline $\begin{array}{l}\text { Keywords: } \\
\text { Quality of Learning, Covid } \\
19\end{array}$ & $\begin{array}{l}\text { used is literature study with } \\
\text { analytical techniques in the form of } \\
\text { content analysis. The results of this } \\
\text { study are that the government has } \\
\text { done to maintain the quality of } \\
\text { learning by promoting the concept } \\
\text { of independent learning proclaimed } \\
\text { by the Ministry of Education and } \\
\text { Culture, then strengthened with a } \\
\text { joint decree covering the Ministry } \\
\text { of Education and Culture, Ministry } \\
\text { of Religion, Ministry of Health and } \\
\text { Ministry of Foreign Affairs } \\
\text { concerning guidelines for } \\
\text { organizing learning in the year new } \\
\text { academic teachings during the } \\
\text { pandemic corona virus disease } \\
\text { (Covid-19), and in its realization } \\
\text { strengthened by the issuance of } \\
\text { covid } 19 \text { emergency curriculum } \\
\text { guidelines by the Directorate } \\
\text { General of Islamic Education the } \\
\text { Ministry of Religion published } \\
\text { curriculum guidelines during } \\
\text { Covid-19 emergencies for } \\
\text { Madrasah. This guide is listed in } \\
\text { the Decree of the Director General } \\
\text { of Islamic Education Ministry of }\end{array}$ \\
\hline
\end{tabular}




Religion. The guide actually
provides an open space for
learning managers to be able to
accurately determine learning
targets. The three efforts are
expected to maintain the quality of
learning even if they are not able to
run optimally.

\section{Pendahuluan}

Indonesia merupakan salah satu negara kawasan Asia yang terdampak wabah covid 19 sekalipun termasuk kategori akhir setelah negara tetangga seperti Malaysia, singapura. Akan tetapi hingga sekarang jumlahnya mengalami peningkatan sebagaimana data yang dirilis oleh Gugus Tugas Penanganan Covid 19 per tanggal 21 Juni pasien terkonfirmasi positif bertambah 862 menjadi 45.891, pasien sembuh 18.404 dan meninggal dunia 2.465 orang. Adapun data secara global Dilansir TribunStyle.com dari worldometers.info pukul 07.00 WIB, kasus covid-19 di seluruh dunia (Senin 22 juni 2020) yakni mencapai 9,044,544 kasus. Sementara itu kematian akibat Covid-19 kini berjumlah 470,665 jiwa. Peningkatan juga terjadi pada angka pasien sembuh berada pada angka 4,837,939 orang, tiga besar negara dengan jumlah kasus Covid-19 tertinggi ialah Amerika Serikat, Brazil, dan Rusia. Amerika Serikat bahkan telah tembus 2,3 juta kasus hingga saat ini.

Data lengkapnya sebagai berikut; Amerika Serikat (Jumlah kasus 2,356,657, Meninggal dunia 122,247,Sembuh 980,355) Brazil (Jumlah kasus 1,086,990, Meninggal dunia 50,659, Sembuh 579,226) Rusia (Jumlah kasus 584,680, Meninggal dunia 8,111, Sembuh 339,711) India (Jumlah kasus 426,910, Meningal dunia 13,703, Sembuh 237,252. UK Jumlah kasus 304,331, Meninggal dunia 42,632, Sembuh N/A, Spanyol, Jumlah kasus 293,352, Meningal dunia 28,323, Sembuh N/A, Peru, Jumlah kasus 254,936, Meninggal dunia 8,045, Sembuh 141,967, Chili, Jumlah kasus 242,355, Meninggal dunia 4,479, Sembuh 200,569, Italia Jumlah kasus 238,499, Meningal dunia 34,634, Sembuh 182,893, Iran, Jumlah kasus 204,952, Meningal dunia 9,623, Sembuh 163,591, Sementara itu China menempati urutan 21 dengan total 83,352 kasus Indonesia 
kini menempati posisi 29 dengan 45,891 kasus, 2,465 meninggal dunia,dan18,404sembuh.(https://mataram.tribunnews.com/2020/06/2 2)

Pandemi ini memberikan dampak yang sangat serius dan masif hampir diseluruh aspek kehidupan. Dalam Aspek sosial masyarakat selama ini melakukan interaksi sosial secara inten kini untuk sementara waktu tidak bisa melakukan interaksi secara langsung dan berkumpul dalam jumlah banyak diganti dengan interaksi berbasis daring (online) dan jika berkumpulpun wajib mengatur jarak 1 hingga 1.5 meter. Aspek ekonomi juga terkena dampak yakni melambannya laju pertumbuhan ekonomi disebabkan frekuensi transaksi ekonomi yang terhambat, tertutupnya investasi diberbagai sektor ekonomi. Aspek politik seperti Pilkada serentak yang rencana digelar bulan aprilpun juga termasuk terdampak dan terpaksa ditunda sampain waktu yang memungkinkan. Aspek agama juga sempat terdampak karena seluruh umat beragama diminta untuk tidak beribadah dengan berkerumun dengan orang banyak melainkan beribadah di rumah masing-masing. Aspek pariwisata, beberapa wisata yang hampir tiap pekan dibanjiri pengunjung baik wisatawan domestik hingga mancanegara, kini tidak seramai biasanya.

Aspek pendidikan termasuk yang terdampak dan sangat kompleks, karena proses pembelajaran yang semestinya dilaksanakan dengan adanya interaksi antara guru dan siswa, namun semuanya berubah total, sejak bulan maret proses pendidikan diseluruh level jenjang pendidikan dilaksanakan secara online/ pembelajaran jarak jauh (PJJ). Dipastikan bahwa target kurikulum tidak dapat tercapai $100 \%$ keputsan tersebut tertuang dalam instruksi presiden melalui mendikbud dengan surat edaran Nomor 4 Tahun 2020 tentang Pelaksanaan Pendidikan dalam Masa Darurat Coronavirus Disease (Covid-19). Keputusan ini tentu telah melalui kajian yang cermat, sekalipun sejak awal telah menuai pro dan kontra khususnya dikalangan para akademisi dan praktisi pendidikan, mesekipun pemerintah sendiri meyakini bahwa pembelajaran online bukanlah solusi efektif yang dapat menunjang proses pembelajaran, tapi keputusan tersebut adalah tepat dan cepat dalam situasi pandemi covid 19 dengan tujuan bahwa itu dapat menekan laju penyebarannya.

Sejak bulan maret penulis telah melakukan pengamatan tentang efektifitas pembelajaran online di sekolah maupun peruguran tinggi. 
Hasilnya bahwa hampir sebagian besar siswa dan guru bahkan orang tua mengeluh tentang pembelajaran online, hal itu muncul dikarenakan terdapat beberapa problem yang secara global dapat digolongkan dalam beberapa aspek seperti kemampuan teknis, ketersedian alat dan jaringan internet, pembiayaan, interaksi dan motivasi belajar mengajar.

Ditempat lain juga memiliki situasi yang hampir sama seperti di jawa timur, hasil survei dilakukan oleh Pimpinan Wilayah Ikatan Pelajar Nahdlatul Ulama (IPNU) Jawa Timur. Ada 88,75 persen responden yang menganggap sistem kegiatan belajar mengajar (KBM) saat ini menjenuhkan, membosankan dan membuat stres," temuan lain menunjukkan 82 persen responden mengaku lebih senang belajar di sekolah, 15 persen menyatakan lebih senang belajar daring, dan sisanya menyatakan tidak tahu.ungkap Muntadiin, Kompas.com, Kamis, (16/4/2020).

Berdasarkan kalender akademik pendidikan tahun ajaran 20192020 telah berakhir dan akan segera masuk tahun ajaran 2020-2021, namun sampai saat ini upaya normalisasi pendidikanpun masih belum menunjukkan kejelasan karena masih terdapat pro dan kontra, disatu fihak pemerintah yakni Kementerian Pendidikan dan Kebudayaan (Kemendikbud) sendiri menegaskan bahwa tahun ajaran baru 2020/2021 akan tetap dimulai pada 13 Juli 2020. Sementara Ikatan Dokter Anak Indonesia (IDAI) mengajanjurkan sekolah tidak dibuka setidaknya sampai bulan Desember 2020 dan kegiatan belajar mengajar tetap dilaksanakan melalui skema pembelajaran jarak jauh (PJJ) baik secara dalam jaringan maupun luar jaringan. Pembukaan kembali sekolah-sekolah, dapat dipertimbangkan jika jumlah kasus COVID-19 telah menurun (Kompas.com. 31/05/2020).

Survei lain dilakukan oleh Komisioner KPAI Bidang Pendidikan Retno Listyarti menyatakan bahwa $80 \%$ dari responden orang tua menolak sekolah dibuka kembali di tengah pandemi Covid-19 ini. Sebaliknya, 80\% siswa setuju sekolah dibuka kembali 20\% itu tidak, untuk guru 60\% setuju dibuka $40 \%$ tidak," (Haidar Rais, prfmnews.pikiran-rakyat.com, 29 Mei 2020). Mencermati data tersebut semakin menguatkan bahwa normalisasi pendidikan belum ada kata sepakat dari seluruh pihak yang terkait.

Terlepas dari pro kontra di atas, anggap saja kemudian disepakati PJJ atau pembelajaran daring sampai berlangsungnya 
tahun ajaran baru, maka pemikiran berikutnya bagaimana upaya menjaga mutu pendidikan dimasa pandemi seperti saat ini, karena jika kondisi pembelejaran yang tidak efektif ini dibiarkan berlarutlarut maka akan menjauhkan pendidikan dari standar mutu yang harus dimiliki.

Mutu dalam persfektif pendidikan dimaknai sebagai kepuasan para pelanggan, sebagaimana diungkapkan Philip Crosby (Crosby, 1992:7) dan Edward Sallis menyatakan bahwa "Quality is unification of product attributes that showing its ability on fulfilling requirements from direct or indirect costomers, implicit and unimplicit requirements." (Sallis, 2004:88). Dengan demikian dalam situasi bagaimanapun maka pendidikan harus dapat memberikan pelayanan yang terbaik supaya pelanggan seperti siswa, orang tua selalu mendapatkan kepuasan atas proses pembelajaran yang dilaksanakan. Keterlibatan seluruh fihak tentunya menjadi penentu keberhasilan sekolah untuk dapat menjaga mutu dengan baik. Selain itu dalam menjaga mutu pendidikan perlu memperhatikan komponenkomponen mutu diantaranya kepemimpinan yang berorientasi pada mutu, pendidikan dan pelatihan, struktur pendukung, komunikasi, ganjaran dan pengakuan dan pengukuran.(Tim Dosen UPI, 2009:302304).

Pembelajaran merupakan suatu sistem intruksional yang mengacu pada seperangkat komponen yang saling bergantung satu sama lain untuk mencapai tujuan. Selaku suatu sistem, pembelajaran meliputi suatu komponen, antara lain tujuan, bahan, peserta didik, guru, metode, situasi dan evaluasi. (Anissatul Mufarokah,2009:43)

Oleh karena itu penelitian ini memiliki nilai penting dan aktual untuk dilaksanakan, karena akan dapat dijadikan sebagai pijakan atau pedoman oleh para guru, kepala madrasah/ sekolah dan praktisi pendidikan untuk memberikan support berupa mindset pendidikan dimasa pandemi covid 19 yang relevan sesuai dengan kebutuhan dan keterjangkauan oleh seluruh pihak atau stake holder.

\section{Metode penelitian}

Jenis penelitian dan pendekatan

Jenis penelitian ini adalah penelitian kualitatif dengan pendekatan studi pustaka, adapun prosedur penelitian yang dilakukan dengan mengkaji secara mendalam dengan meningintegrasikan antara fakta dilapangan dengan teori-teori yang relevan sehingga 
menghasilkan sebuah konsep baru yang dapat diimplemtasikan pada objek yang memiliki kemiripan situasi.

\section{Teknik pengumpulan data}

Dalam penelitian kepustakaan, metode yang digunakan untuk mengumpulkan data penelitian berupa data-data kepustakaan yang telah dipilih, dicari, disajikan dan dianalisis. Sumber data penelitian ini mencari data-data kepustakaan yang substansinya membutukan tindakan pengolahan secara filosofis dan teoritis.

\section{Waktu dan Tempat Penelitian}

Penelitian ini diselesaikan secara mandiri di rumah sejak tanggal 10-23 Juni 2020.

\section{Fokus Penelitian}

Fokus penelitian ini adalah untuk mendeskripsikn tentang upaya menjaga mutu pembelajaran ditengah pandemi covid 19.

\section{Sumber Data Penelitian}

Sumber data dalam penelitian ini adalah digolongkan menjadi dua primer dan skunder. Data primer yang dimaksud adalah pustaka rujukan utama yaitu buku manajemen mutu pendidikan, adapun data skunder merupakan data berbentuk litaratur dan fakta dilapangan yang akan dikaji menjadi bagi penentuan konsep dalam literatur.

\section{Analisi data}

Adapun dalam penelitian ini menggunakan teknik analisi data berupa analisis isi (content analysis). Analisis isi merupakan analis ilmiah tentang isi pesan suatu data (Muhadjir, 1998: 49)

\section{Pembahasan}

\section{Deskripsi Perkembangan Pandemi covid 19 di Indonesia.}

Covid 19 merupakan jenis virus baru yang telah menyita perhatian seluruh dunia, hampir 6 bulan sejak kasus virus corona jenis baru pertama kali diidentifikasi di Wuhan, China, dan pandemi masih berlangsung hingga saat ini. Kasus-kasus baru di berbagai negara masih bertambah setiap harinya. Melansir data dari laman Worldometers, Senin (15/6/2020), jumlah total kasus virus corona di dunia adalah sebanyak 7.981 .570 (7,98 juta) kasus. Dari 
angka tersebut, tercatat 435.159 kasus kematian dan 4.103 .335 (4,1 juta) pasien telah dinyatakan sembuh. Adapun kasus aktif saat ini adalah sebanyak 3.443.076 (3,4 juta) dengan 3.388 .965 (3,4 juta) kasus kondisi ringan dan 54,111 kondisi serius. Kasus total terbanyak masih dicatatkan oleh AS, dengan lebih dari 2 juta kasus, disusul Brazil, Rusia, India, dan Inggris.

Perkembangan kasus dan penanganan virus corona terus terjadi di berbagai negara di dunia. Berbagai upaya dilakukan untuk menekan laju penyebaran covid 19, akan tetapi upaya-upaya negara maju untuk menemukan vaksin hingga saat ini belum menampakkan hasilnya.

Selain itu perkembangan covid 19 di dunia, Indonesia juga memiliki kasus yang tidak dipandang remeh, tiap hari jumlah mengalami kenaikan yang signifikan, hal ini dapat dilihat dari data yang dirilis dilaman gugus covid 19 pertanggal 21 Juni 2020 sebagai berikut:

Gambar 1. Jumlah kasus terkonfirmasi covid 19
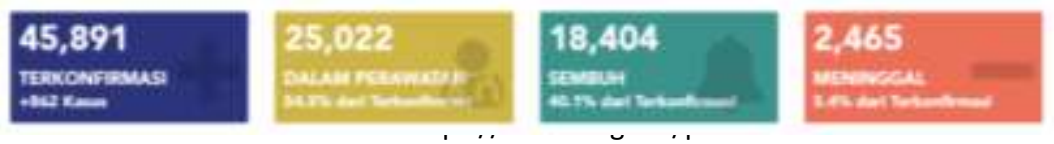

Adapun penambahan secara lebih rinci dapat dilihat dari sebaran peta covid 19 dibawah ini:

Gambar 2. Jumlah kasus terkonfirmasi covid 19 per hari

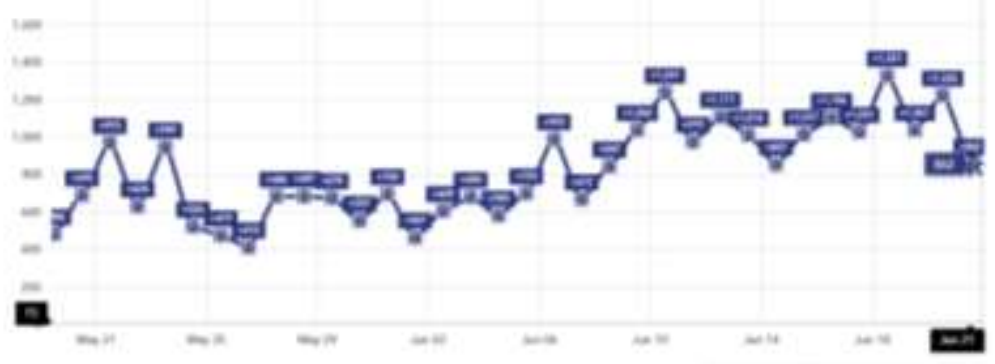

Sumber https://covid19.go.id/peta-sebaran

Gambar di atas menunjukkan bahwa perkembangan kasus ini bersifat fluktuatif, namun kecenderungan peningkatan signifikan sejak tanggal 10 Juni hingga tanggal 18 Juni 2020, yang angkanya mencapai 1331 hal itu bersamaan dengan kebijakan presiden yang menghendaki new normal (kebiasaan baru). Salah satu 
kebijakaannya pemerintah melonggarkan kebijakan penangan wabah ini, mulai dari pencabutan status PSBB di beberapa wilayah sekalipun wabah ini masih sangat mengancam, selain itu pemerintah juga membuka kembali pusat perkumpulan masa seperti pasar, mall dan tempat keramaian lainya dengan tetap memperhatikan protokol covid 19.

Kemudian disamping terdapat kenaikan korban terpapar, kanaikan lagi dikasus paseien sembuh adapun rinciannya dapat dilihat pada gambar 3 dibawah ini.

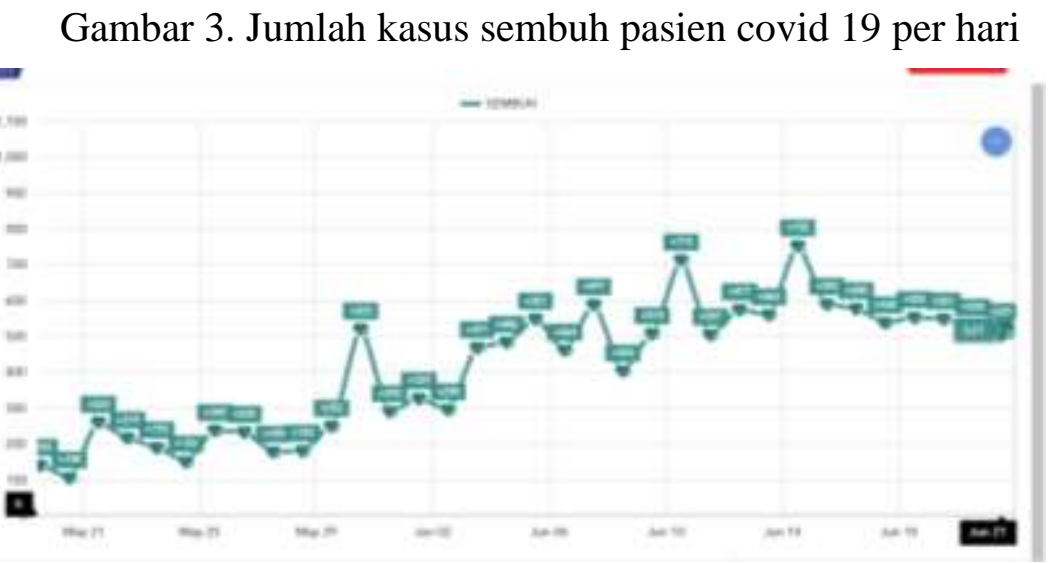

Sumber https://covid19.go.id/peta-sebaran

Peta sebaran di atas memberikan informasi bahwa fenomena pasien sembuh mengalami kenaikan signifikan juga, sekalipun flulutiatif tapi kecenderungannya lebih banyak mengalami kenaikan terutama pada tanggal 10 dan 14 Juni mencapai angka 755 orang yang sembuh. Angka ini tentu sedikit mengurangi kekhawatiran masyarakat, sekurang-kurangnya dapat merubah mindset tentang covid 19 yang semula ketakutan, kecemasan, kini masyarakat punya keyakinan bahwa pasien virus ini bisa disembuhkan.

Gambar 4. Jumlah kasus meninggal pasien covid 19 per hari

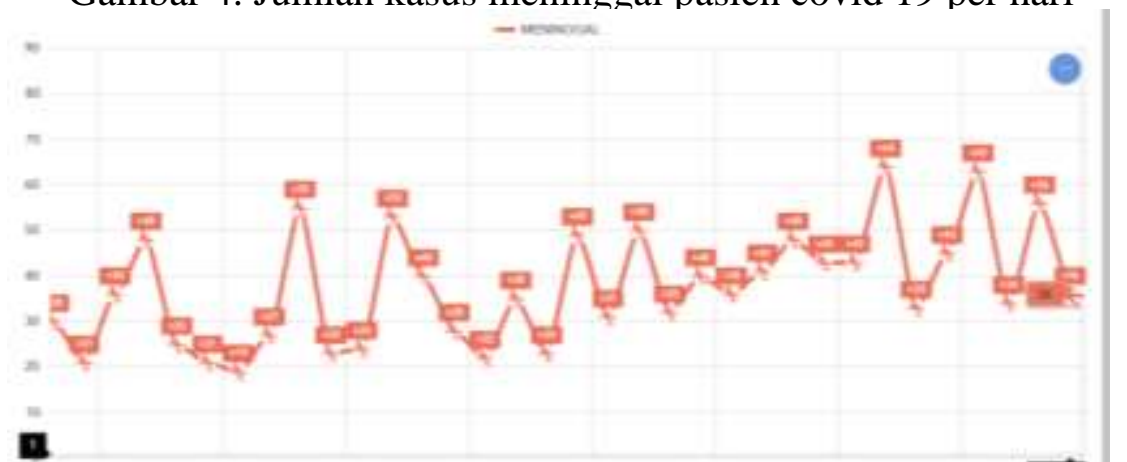


Grafik peta di atas menunjukkan adanya trend penurunan kasus kematian pasien covid 19 ini, sekalipun pernah terjadi kenaikan pada tanggal 15 Juni 2020 yang mencapai 64 kasus, sedangkan pada hari berikutnya mengalami penurunan yang signifikan hingga mengalami penurunan 32 angka. Kita berharap bahwa kasus meninggal selalu mengalami penurunan seiring dengan kesadaran masyarakat yang semakin meningkat.

\section{a. Kondisi Pembelajaran di tengah Pandemi covid 19}

Sejak akhir maret 2020 siswa maupun mahasiswa se Indonesia melakukan proses pembelajaran jarak jauh alias via online, hal itu selaras dengan instruksi president RI melalui mendikbud yang memerintahkan belajar online selama masa pandemi covid 19, keputusan ini ditetapkan tentu sudah melalui kajian yang seksama, dengan dalih sebagai upaya untuk menekan laju penyebaran virus ini, pertimbangan itu sangat logis.

Namun demikian, ternyata kebijakan inipun tidak nihil dari cela yang memiliki multi effect baik dirasakan oleh guru maupun siswa, dan sekolah. Tema sudah santer dibahas dibeberapa media online maupun televisi, dan ini fakta terang benderang yang dapat dilihat oleh kalangan manapun, apalagi arus medsos sudah semakin deras menjadi media komunikasi massal.

Sebelum dilanjut, perlu ditegaskan lebih awal bahwa ulasan ini bukan bermaksud mencari sisi negative, melainkan penulis mencoba merekam situasi riil dilapangan, sehingga kita bisa bersama-sama berbuat untuk melakukan perbaikan. Jika situasi ini dibebankan sepenuhnya kepada pemerintah, maka dapat dipastikan tidak akan terselesaikan, karena ini bukan fenomena yang 
lokalistik tapi sudah Jamak alias nasional. Ada tiga sisi central yang akan diulas secara sederhana yaitu siswa, guru, orang tua siswa. Sisi tersebut merupkan unsur inti dalam system pendidikan.

Dari fihak siswa memiliki banyak hal yang menghambat laju belajar online (daring) sehingga mengalami kesulitan. Pertama, aspek tekhnologi. Tidak semua siswa memiliki perangkat dan mampu mengoperasikan smart phone (HP cerdas) dengan fiturfitur baru yang menunjang belajar online (e learning), belum lagi terbatasnya aksesbilitas internet, karena tidak semua siswa bertempat tinggal di daerah kota yang lengkap sarana komunikasi, melainkan banyak juga yang tinggal di pelosok desa dan belum tersentuh sarana tersebut. Kedua, aspek motivasi belajar. Aspek ini benar-benar tidak bisa terdekteksi secara baik oleh guru, tapi hal itu bisa dicermati dari antusiasme dalam mengikuti pembelajaran online. Dari beberapa guru yang dikonfirmasi menyatakan maksimal angka partisipasi siswa maksimal $40 \%$ dari jumlah semestinya, dan itupun fluktuatif (pasang surut) faktor penyebabnya kompleks sekali seperti internal siswa, support orang tua yang relatif rendah, biaya, termasuk aspek tekhnologi.

Dari pihak guru juga mengalami beberapa persoalan, Pertama tidak semua guru mahir dengan tekhnologi smart phone apalagi guru-guru yang telah lanjut usia, tentu cukup rumit untuk mengikuti pola ini. Kedua, Aspek waktu, ketika di sekolah pembelajaran tetap muka bisa terjaduwal dengan tertib, tapi bagi guru-guru yang punya tugas mengatur rumah tangga tentu sesuatu yang ekstra, kerena harus mengatur dua kegiatan yang bersamaan, satu sisi harus fokus online satu sisi harus menjalankan fungsinya sebagai bapak atau ibu bagi keluarganya. Ketiga, biaya, dengan pembelaajaran online maka perlu ada alokasi dana untuk internet setidaknya Rp. 50.000-100.000/ bulan harus disiapkan, lebih-lebih jika menggunakan pola confrence (zoom meeting, google meet dll) tentu lebih dari itu, ini sangat sulit bagi guru-guru honorer disekolah swasta dengan gaji 150-250 ribu, itupun jika dibayar tepat waktu, sering terjadi dibayar tiga-lima bulan sekali.

Pihak orang tua, ini tidak kalah kompleks dibanding guru dan siswa. Disamping persoalan tekhnologi, biaya, mereka perlu menyediakan waktu khusus bagi anak-anaknya untuk melakukan pendampingan, bagi orang tua yang terdidik tentu bukan menjadi masalah, tapi bagi mereka yang tidak ngerti urusan pendidikan ini 
problem serius. Apalagi bagi orang tua yang pekerjaannya bersifat fisik dan itu mata pencaharian inti.

Situasi sebagaimana tersebut diatas merupakan dilema tersendiri bagi dunia pendidikan, satu sisi proses pendidikan harus tetap berjalan, disisi lain kekhawatiran akan dampak covid 19 juga tidak bisa diremehkan. Cukup sulit nampaknya membicarakan solusi yang jitu dan bisa menjadi penyelesaian. Sehingga alternatif akhir menggunakan kaidah fiqih yang menyatakan maa lam yudroku kulluh lam yutroku kulluh (jika tidak bisa mendapatkan target seluruhnya maka jangan tinggalkan sama sekali). Jika pembelajaran diliburkan sama sekali dengan jangka waktu yang cukup lama bahkan belum menemui titik terangnya, maka akan timbul dampak yang jauh lebih besar jika dibandingkan dengan dampak-dampak yang bersifat teknis.

Aspek penting yang hilang pada saat pembelajaran jarak jauh adalah urgensi komunikasi interaktif yang dilakukan oleh guru dan peserta didik, komunikasi sendiri memiliki tujuan yang sangat penting diantanya dengan komunikasi yang inten diharapakan adanya perubahan sikap (attitude change); perubahan prilaku (behavior change); perubahan pendapat ( opinion change); perubahan sosial (social change) (Saefullah, 2014:179)

\section{b.Urgensi Menjaga Mutu Pembelejaran di tengah Pandemi covid 19.}

Ahli pendidikan berpendapat bahwa mutu pembelajaran diartikan sebagai mutu dari aktifitas mengajar yang dilakukan oleh guru dan mutu aktifitas belajar yang dilakukan siswa dikelas, dilabolatorium, dan ditempat belajar lainya. Sedangkan mutu hasil proses belajar mengajar adalah mutu aktifitas mengajar yang dilakukan oleh guru dan siswa yang terwujud dalam bentuk hasil belajar nyata yang dicapai oleh peserta didik berupa nilai akademik atau nilai rata-rata mata pelajaran. (Abdul Haris dan Nurhayati, 2010:98-99)

Mutu memiliki pemaknaan yang berbeda-beda sebagaimana yang diungkapkan oleh para ahli:

a. Josep M. Juran.

Juran mendefinisikan kualitas sebagai kecocokan untuk pemakaian (fitnes for use). Definisi ini menakankan orientasi pada pemenuhan harapan pelanggan (Juran, 1989:21); 
b. Philip B. Crosby.

Mutu adalah Conformance to Requirment yaitu sesuai dengan yang diyaratkan dan distandarkan. Pendekatan Crosby menaruh perhatian besar pada tranfomasi budaya kualitas. Ia mengemukakan pentingnya melibatkan setiap orang dalam organisasi pada proses, yaitu dengan jalan menekankan pada kesesuain individu terhadap persyaratan/ tuntutan. Pendekatan crosby merupakan proses top down (Crosby, 1879:34).

c. Edaward Deming.

Meniru Deming, mutu adalah kesesuaian dengan kebutuhan pasar (Deming, 1986:23). Jika konsumen merasa puas maka, maka mereka akan setia dalam membeli produk perusahaan tersebut berupa barang maupun jasa. (Abdul Haris dan Nurhayati, 2010:85)

d. Feigenbaum.

Fagenbaum menyatakan bawah mutu adalah kepuasan pelanggan sepenuhnya (full costumer satisfaction), suatu produk dianggap bermutu apabila dapat memberikan kepuasan sepenuhnya pada konsumen, yaitu sesuai dengan harapan konsumen atas produk yang dihasilkan oleh perusahaan Lihat (Feigenbaum, 1991:32).

Pendapat para ahli manajemen mutu bidang industri diatas, terdapat dua arus pemikiran tentang konsep mutu. Menurut kelompok Pertama, bahwa kepuasan pelanggan menjadi target yang harus dicapai dalam penjualan produk. Artinya pelaggan sebagai sasaran utama dalam penjualan produk harus diperhatikan tingkat kepuasannya, bukan sekedar produk terjual. Oleh karena itu ukuran terpenting dalam menentukan mutu, yaitu kepuasan pelanggan. Kelompok kedua, bahwa sesuatu produk memiliki kualitas apabila sesuai dengan standar kualitas yang telah ditentukan. Standar kualitas bahan baku, proses produksi, dan produk jadi. Apa yang menjadi mutu adalah standarisasi; jika standar yang ditetapkan sudah tercapai, maka ditingkatkan standar yang baru secara terus menerus tanpa akhir. (Makbullah, 2011:3335)

Mencermati dua pemikiran besar tentang mutu di atas jika dikaitkan dengan mutu pembelajaran di sekolah memiliki implikasi pada dua hal. 
Pertama, bagaimana lembaga pendidikan mampu memfasilitasi dan mengelola proses pembelajaran yang dapat menciptakan kepuasan sebagaimana harapan para siswa, dan orang tua. Harapan pada proses pembelajaran tentu yang diharapkan adalah peningkatan prestasi belajar, baik bersifat akademik maupun non akademik. Akademik ditunjukkan dengan bertambahnya pengetahuan dan pengalaman siswa hal yang sering disebut dengan istilah kogintif, afektif dan psikomotorik. Selain itu guru harus menjadikan peserta didik memiliki kecakapan untuk belajar dan memperoleh pengetahuan tentang cara belajar yang efektif (learning how to learn). Untuk itu guru harus mampu menciptakan iklim belajaryang menyenangkan (joyful learning) sehingga peserta didik tidak merasa tertekan atau terpaksa ketika menghadapi pembelajaran. (Mulyasa, 2002:149)

Kedua, fihak sekolah atau madrasah harus mengupayakan bagaimana proses pembelajaran dapat sesuai standar yang telah ditetapkan oleh fihak sekolah. Oleh karena itu dalam rangka mewujudkan mutu pembelajaran yang berkualitas, pemerintah mengeluarkan Peraturan Pemerintah No. 19 tahun 2005 tentang Standar Nasional Pendidikan (SNP) sebagai penjabaran lebih lanjut dari Undang-undang Sistem Pendidikan Nasional, yang di dalamnya memuat tentang standar proses. Selain itu lebih lengkapnya merujuk pada ketentuan 8 standar nasional pendidikan (SNP) (8) SNP yang dimaksudkan meliputi : (1) standar isi, (2) standar proses, (3) standar kompetensi lulusan, (3) standar pendidik dan tenaga kependidikan, (5) s.tandar sarana dan prasarana, (6) standar pengelolaan, standar pembiayaan, dan (8) standar penilaian pendidikan.

Pembelajaran merupakan proses yang sangat komplek yang melibatkan banyak unsur, sebgaimana yang diungkapkan oleh Hamalik (2014:57), pembelajaran adalah suatu kombinasi yang tersusun meliputi unsur-unsur manusiawi, material, fasilitas, perlengkapan, dan prosedur yang saling mempengaruhi mencapai tujuan pembelajaran. Kemudian (Suhardan, 2010:67) mengemukakan pembelajaran pada dasarnya merupakan kegiatan akademik yang berupa interaksi komunikasi anatara pendidik dan peserta didik proses ini merupakan sebuah tindakan professional yang bertumpu pada kaidah-kaidah ilmiah. Aktivitas ini 
merupakan kegiatan guru dalam mengaktifkan proses belajar peserta didik dengan menggunakan berbagai metode belajar.

Berkaitan dengan pembelajaran yang bermutu, Mulyono (2009:29) menyebutkan bahwa konsep mutu pembelajaran mengandung lima rujukan, yaitu: 1. Kesesuaian, 2. Pembelajaran, 3. Efektivitas, 4. Efisiensi, 5. Produktivitas. Pembelajaran yang bermutu akan bermuara pada kemampuan guru dalam proses pembelajaran. Secara sederhana kemampuan yang harus dimiliki oleh guru yaitu kemampuan merencanakan pembelajaran, proses pembelajaran, serta evaluasi pembelajaran.

Kemampuan merencanakan pembelajaran merupakan suatu yang fundamental karena keberhasilan pendidikan akan dapat diprediksi dari sisi perencanaan, jika baik perencanaan maka potensi besar akan untuk dapat mencapai target, oleh karena itu terdapat prinsip "gagal merencanakan sama halnya sedang merencanakan kegagalan.

Oleh karena itu dalam merencanakan harus memiliki prinsipprinsip yang matang diantaranya 1) perencanaan hendaknya memiliki nilai dasar yang jelas dan mantap seperti nilai budaya, nilai moral dan religius ataupun gabungan ketiganya; 2) perencanaan hendkanya bersifat realistis maksudnya disesuaikan dengan sumber daya dan dana yang tersedia bukan sumber daya yang diperkirakan; 3) perencanaan hendaknya fleksibel artinya memungkinkan terjadi diluar perecanaan maka diperlukan opsi atau pilihan tindakan lainya sebagai bentuk ansisipasi. (Saefullah, 2014:238)

Hamid Darmadi selanjutnya menegaskan bahwa perencanaan persiapan mengajar sesungguhnya bertujuan mendorong guru agar lebih siap melakukan kegiatan pembelajaran dengan perencanaan yang matang. Oleh karena itu, setiap akan melakukan pembelajaran guru wajib melakukan persiapan, baik persiapan tertulis maupun tidak tertulis.(Darmadi, 2009:115)

Selanjutnya Syaiful Sagala menyebutkan bahwa pembelajaran mempunyai dua karakteristik, yaitu: Pertama, proses pembelajaran melibatkan proses mental siswa secara maksimal, bukan hanya menuntut siswa sekedar mendengar, mencatat, tetapi menghendaki aktivitas siswa dalam proses berpikir. Kedua, dalam proses pembelajaran dibangun suasana dialogis dan proses tanya jawab terus menerus yang diarahkan untuk memperbaiki dan 
meningkatkan kemampuan berpikir siswa, yang pada gilirannya kemampuan berpikir itu dapat membantunya untuk memperoleh pengetahuan yang mereka konstruksi sendiri. (Sagala, 2005:63)

Untuk dapat melaksanakan pembelajaran yang efektif seorang guru harus dapat memilih pendekatan yang tepat diantaranya pendekatan kompetensi, pendekatan keteampilan proses, pendekatan lingkungan, pendekatan konteksual dan pendekatan tematik. Jika pendekatan telah diperoleh maka langkah berikutnya adalah menentukan metode pembelajaran. Penggunaan metode yang tepat akan turut menentukan efektifitas dan efisiensi pembelajaran (Mulayasa, 2011:107)

Kemudian langkah yang penting lainya adalah evaluasi pembelajaran. Menjaga mutu pembelajaran merupakan hal yang mutlak harus dilakukan oleh setiap lembaga pendidikan, baik itu dalam situasi stabil maupun dalam keadaan yang tidak menentu seperti pandemi covid 19 yang hingga saat inipun belum ada tanda-tanda berakhir. Sehingga situasi menuntut para stake holder pendidikan harus cermat membaca situasi dan peluang yang strategis untuk menyelenggarakan pembelajaran yang efektif dan efisien.

Para ahli memberikan indikator mutu proses belajar mengajar sekurang-kurang terdapat 23 indikator diantaranya : 1) guru membuka pelajaran dengan ucapan salam, 2) guru melakukan presensi siswa; 3) guru melakukan pengelolaan kelas;4) guru menjelaskan materi pelajaran di kelas;5) guru memberikan kesempatan kepada siswa untuk bertanya; 6) guru menjawab pertanyaan siswa; 6) guru memberikan pertanyaan kepada siswa; 7) guru memberikan penguatan; 8) guru mengajukan pertanyaan dasar dan lanjutan; 9) guru memberikan vareasi dalam teknik mengajar; 10) guru menggunakan stimulus untuk membangkitkan minat dan motivasi belajar siswa; 11) guru mengadakan pengajaran di kelompok kecil; 12) guru memimpin diskusi kelompok; 13) guru mengajar atas dasar perbedaan individu ; 14) guru mengajar melalui penemuan siswa; 15) guru mengembangkan kreatifitas siswa; 16) guru memberikan kegiatan pengayaan dan remidial kepada siswa; 17) guru memberikan tugas belajar kepada siswa baik individual maupun kelompok; 18) guru menilai sikap dan prilaku kerjasama siswa dalam mengikuti proses belajar mengajar; 19) guru menilai penguasaan siswa terhadap 
materi pelajaran dengan tes formatif; 20) guru memperjelas kembali jawaban siswa atas pertnyaan siswa lain; 21) guru menarik kesimpulan tentang pokok bahasan yang diajarkan pada akhir pertemuan di kelas; 22) guru memberikan pekerjaan rumah kepada siswa dan 23) guru menutup pelajaran dengan ucapan salam. Sedangkan indikator mutu hasil belajar ialah nilai rata-rata hasil belajar siswa (Abdul Haris dan Nurhayati, 2010: 98-99)

Mencermati indikator-indikator di atas jika dihubungkan dengan situasi pandemi ini tentu akan mengalami problem baru, interaksi langsung di ruang kelas antara guru dan murid harus dibatasi bahkan ditiadakan sama sekali demi mencegah penyebaran virus. Hal ini dilakukan karena protokol kesehatan yang mengharuskan setiap individu melakukan social dan physical distancing bukan pengecualian dalam interaksi belajar-mengajar antara guru dan murid. Akibat pandemi, kegiatan belajar mengajar (KBM) pun secara mendadak harus dijalankan dengan menggunakan sistem belajar jarak jauh melalui jaringan internet atau daring. Pendidik dan peserta didik yang terbiasa melakukan KBM dengan interaksi langsung di ruang kelas, suka tidak suka, harus menyesuaikan diri dan menerima metode belajar jarak jauh itu sebagai satu-satunya jalan dalam melaksanakan KBM. Dalam konteks inilah kualitas KBM dan lebih luas lagi kualitas pendidikan nasional kita mulai dipertanyakan. Keraguan bahwa kualitas dunia pendidikan nasional kita bakal menurun pun mulai mengemuka.(https://mediaindonesia.com/editorials/detail_editorial s/1998-mutu-pendidikan - di-tengah-pandemi)

Situasi tersebut mendapat tanggapan serius dari pemerintah, sekalipun tentu tidak akan ada satu solusi yang nihil dari persoalan untuk menghadapi siatuasi ini, oleh karena itu Mendikbud memberikan kunci penting bahwa untuk dapat menjaga mutu pembelajaran sekarang ialah guru harus faham dan sadar tekhnologi, guru harus berani mengunakan aplikasi, fitur-fitur baru untuk menunjang pembelajaran daring hal itu disampaikan Nadiem dalam acara halal bihalal Asosiasi Dosen Indonesia (ADI) secara daring di Jakarta, Selasa (9/6/2020).

Dalam pembelajaran daring atau online maka guru dituntut harus bisa memilih media yang tepat atau fitur yang efektif. Oleh karena menurut Arsyad perlu mempertimbangkan beberapa aspek dalam memilih media belajar, diantaranya a) kemampuan 
mengakomodasikan penyajian stimulus yang tepat (visual dan audio visual); b) kemampuan mengakomodasikan respons siswa yang tepat (tertulis, audio dan kegiatan fisik); c) kemampuan mengakomodasikan umpan balik; d) pemilihan media utama dan media sekunder untuk penyajian informasi atau stimulus. (Arsyad, 2007: 71)

Upaya menjaga mutu dari sisi kebijakanpun telah dilakukan oleh pemerintah diantaranya kemendikbud yang memberikan istilah sekolah merdeka, konsep tersebut seseungguhnya memberikan kelonggaran atau kebebasan pada satuan pendidikan untuk dapat menyelenggarakan pendidikan dengan dinamis sesuai dengan kemampuan dan keterjangkauan.

Kemudian kebijakan berikutnya adalah diterbitkannya keputusan bersama 4 kementerian. Kementarian pendidikan dan kebudayaan, Kementerian Agama, Kementerian Kesehatan dan Kementerian Luar Negeri tentang panduan penyelenggaraan pembelajaran pada tahun ajaran akademik baru di masa pandemi corona virus disease (Covid-19),

Panduan tersebut memuat sebuah prinsip penting bahwa "kesehatan dan keselamatan peserta didik, pendidik, tenaga kependidikan, keluarga dan masyarakat menjadi prioritas utama dalam menetapkan kebijakan pembelajaran". Kemudian secara subtantif keputusan bersama tersebut mengandung tiga upaya penting dalam menjaga mutu pembelajaran, yaitu 1) pola pembelajaran. Proses pembelajaran diatur dengan dua pilihan berdasar status daerah masing-masing. Untuk zona kuning, orange, dan merah proses pembelajaran tetap dilaksanakan dari rumah (PDR/ daring), adapun untuk zona hijau pembelajaran boleh dilaksanakan di sekolah dengan tetap memenuhi standar protokol kesehatan covid-19.

Dalam realisasinya pembelajaran tatap muka pada zona hijau dibagi menjagi dua tahapan, gambaranya adalah sebagai berikut:

Gambar 5. Fase pendidikan bagi wilyah zona hijau

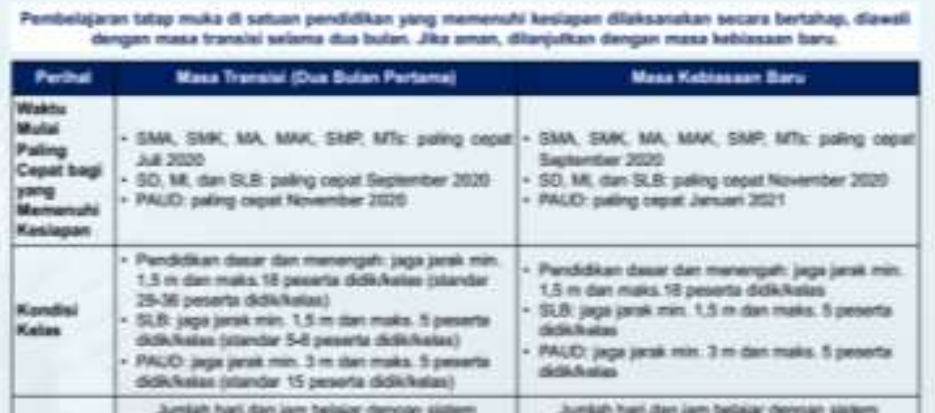


Sumber. keputusan bersama 4 kementerian tahun 2020.

Dana Bantuan Operasional Sekolah (BOS) kini dicurahkan untuk memperlancar proses pembelajaran di sekolah maupun daring baik untuk guru maupun siswa, bahkan prosentasi pembiayaan untuk honor guru naik menjadi 50\% dari ketentuan semestinya. Ini satu upaya menjaga mutu, karena sebagaimana disebutkan dalam latar belakang bahwa faktor biaya ini menjadi kendala tersendiri baik dari guru maupun dari siswa, sehingga dengan adanya keputusan tersebut tentu diharapkan kendalakendala tersebut bisa diatasi, dan KBM daring bisa lebih optimal.

Upaya lainya adalah Direktorat Jenderal Pendidikan Islam Kementerian Agama menerbitkan panduan kurikulum pada masa darurat Covid-19 untuk madrasah. Panduan ini tercantum dalam Surat Keputusan Direktur Jenderal Pendidikan Islam Kementerian Agama Nomor 2791 Tahun 2020, tertanggal 18 Mei 2020. Panduan itu menjadi penting adanya, hal ini berkenaan juga dengan usulan dari berbagai organisasi dan serikat guru termasuk komisi perlindungan anak (KPI) yang melihat situasi yang harus diberikan alternatif. Panduan tersebut memuat hal penting sebagaimana disampaikan oleh Wakil Sekretaris Jenderal FSGI, Satriwan Salim "Ada relaksasi konten (standar Isi) kurikulum, standar penilaian, standar proses, standar kompetensi lulusan; termasuk standar sarana-prasarana," (Kompas.com).

Kebijakan-kebijakan yang telah dilakukan oleh pemerintah sudah mencerminkan upaya menjaga mutu pembelajaran di setiap satuan pendidikan, sekalipun kemudian ada penyesuaian target kurikulum yang diformat ulang sesuai dengan situasi pandemi saat ini. Bagaimanapun bahwa proses pembelajaran pada satuan 
pendidikan diselenggarakan secara interaktif, inspiratif, menyenangkan, menantang, memotivasi peserta didik untuk berpartisipasi aktif, serta memberikan ruang yang cukup bagi prakarsa, kreativitas, dan kemampuan sesuai bakat, minat dan perkembangan fisik dan psikologis peserta didik.

Uraian di atas menunjukkan bahwa mutu pembelajaran dianggap bermutu bila berhasil mengubah sikap, perilaku dan keterampilan peserta didik dikaitkan dengan tujuan pendidikannya. Mutu pendidikan sebagai sistem selanjutnya bergantung pada mutu komponen yang membentuk sistem, serta proses pembelajaran yang berlangsung hingga membuahkan hasil belajar yang optimal.

\section{Simpulan}

Mencermati hasil pambahasan di atas bahwa menjaga mutu pembelajaran tetap harus dilakukan sekalipun dengan segala keterbatasan, oleh karena itu upaya pemerintah sudah sangat serius dilakukan, sekalipun ini semua kembali bergantung pada kemampuan satuan pendidikan masing-masing untuk dapat merealisasikan dalam proses pembelajarannya.

Keseriusan menjaga mutu ditunjukkan dengan memunculkan konsep belajar merdeka yang mengadopsi kelonggaran dan fleksibilitas belajar, penyusunan pedoman pembelajaran di masa pandemi dan penerbitan kurikulum darurat yang mencoba memberikan penyederhanan konsep dan target pembelajaran. Namun itu semua kembali kepada bagaiman profesionalitas guru dalam mengelola pembelajaran di tengah pandemi covid 19, jika guru profesional maka pandemi ini bukan menjadi masalah melainkan sebuah tantangan baru untuk memicu memunculkan inovasi baru yang dapat ditranser, dishare kepada peserta didik. 
54 Imam Subhi,Urgensi Upaya Menjaga Mutu,....

A.V Feigenbaum, Total Quality Control, $4^{\text {th }}$ ed 1991. New York: Mc. Graw-Hill.

Abdul Haris dan Nurhayati, 2010. Manajemen Mutu Pendidikan, Bandung: Alfabeta.

Abdurrahman, Mulyono. 2009. Pendidikan Bagi Anak Berkesulitan Belajar. Jakarta: PT Rineka Cipta.

Anissatul Mufarokah, 2009. Strategi Belajar Mengajar, Yogyakarta: Teras,.

Arsyad, 2007. Media Pembelajaran, Jakarta: Rajawali Pers.

Deden Makbullah, 2011. Manajemen Mutu Pendidikan Islam Jakarta: Raja Grafindo

Darmadi, Hamid, 2009. Kemampuan Dasar Mengajar, Cet.I, Bandung: Alfabeta,

E. Mulyasa, 2002. Kurikulum Berbasis Kompetensi, Konsep, karakteristik dan Implementasi, Bandung: Remaja Rosda karya.

2011 Menjadi Guru Profesional Mencipatkan Pembelajaran Kreatif dan Inovatif. Bandung: Remaja Rosda karya.

Edward Sallis, 2004 Total Quality Management in Education, New Jersey: Prentice Hal.Inc.

Hamalik, 2014. Perencanaan Pengajaran Berdasarkan Pendekatan Sistem, Jakarta: Bumi Aksara.

J. M Juran, 1989. Juran On Leadership For Quality, New York: Mcmillan.

Muhadjir, Noeng. 1998. Metodologi Penelitian Kualitatif. Yogyakarta: Rake Sarasin. 
Philip Crosby1992, Quality is Free, New York: Mentor Books.

Philip. B. Crosby, 1987. Quality Is free; The art Of Making Quality Certain (New York: Mc Girl-Hill, 1879.

Suhardan, Dadang. 2010. Supervisi Profesional (Layanan dalam Meningkatkan Mutu. Pengajaran di Era Otonomi Daerah).Bandung: Alfabeta.

Syaiful Sagala, 2005. Konsep dan Makna Pembelajaran.Bandung: Alfabeta.

Tim Dosen Administrasi Pendidikan Universitas Pendidikan Indonesia UPI, 2010. Manajemen Pendidikan , Bandung; Alfabeta.

W. Edward Deming, 1986, Out of Crisis, Cambridge: Cambridge University Press.

Jufri Dolong. 2016 Sudut Pandang Perencanaan Dalam Pengembangan Pembelajaran, Volume V, Nomor 1, Januari Juni 2016 https://covid19.go.id/peta-sebaran (diakses $21 \mathrm{jUni}$ 2020)

Kompas.com dengan judul "Survei: Sistem Belajar Online Membosankan dan Bikin Stres", https:// surabaya. kompas. com/ read/ 2020/04/16/15230481/survei-sistem-belajar-onlinemembosankan-dan-bikin-stres

Kompas.com dengan judul "Ikatan Dokter Anak Anjurkan Sekolah Tidak Dibuka sampai Desember 2020", https:// www. kompas. com/ edu/ read/ 2020/ 05/ 31/ 061839671/ikatan-dokter-anakanjurkan-sekolah-tidak-dibuka-sampai-desember-2020. https://prfmnews.pikiran-rakyat.com/nasional/pr 13390468/komisioner-kpai-sebar-angket-soal-rencana-bukakembali-sekolah-hasilnya-80-orang-tua-tak-setuju

Kompas.com dengan judul "Update Virus Corona Dunia 15 Juni: 7,98 Juta Terinfeksi | Perancis dan Spanyol Akan Buka Perbatasan", https:// www. 
kompas.com/tren/read/2020/06/15/074312765/update-viruscorona dunia-15-juni-798-juta-terinfeksi-perancis-dan-spanyol.

Kompas.com dengan judul "Kemenag Terbitkan Panduan Kurikulum pada Masa Darurat Covid-19 bagi Madrasah", https:// nasional. kompas. com/ $\mathrm{read} / 2020 / 05 / 26 / 08504451 /$ kemenag-terbitkan-panduankurikulum-pada-masa-darurat-covid-19-bagi madrasah?page=all. (diakses 21 Juni 2020) Sumber: https://mediaindonesia.com/editorials/detail_editorials/ 1998-mutu-pendidikan-di-tengah-pandemi

https://www.liputan6.com/news/read/4274890/mendikbud-gurupenentu-kualitas-pembelajaran-daring-di-tengah-pandemicovid-19

Tribunmataram.com dengan judul update Corona Dunia Senin 22 Juni 2020, Total 9 Juta Kasus, 5 Juta Sembuh, Indonesia Urutan ke-29, https://mataram.tribunnews.com/2020/06/22/updatecorona-dunia-senin-22-juni-2020-total-9-juta-kasus-5-jutasembuh-indonesia-urutan-ke-29.Salma Fenty Irlanda 